\title{
DIAGNOSES OF NEW CEPHALOPODS FROM THE HAWAIIAN ISLANDS.
}

\author{
By S. Stillman Berry, \\ of Stanford University, California.
}

Prior to the publication of a final report on the cephalopods collected by the U. S. Bureau of Fisheries steamer Albatross in the Hawaiian Islands it was deemed best to issue the present paper to contain preliminary diagnoses of such forms as are believed to be new, leaving more detailed and completely illustrated descriptions until the appearance of the main report. It is hoped, however, that the following observations will, in the meanwhile, prove useful to other students of the group and sufficient for the ready recognition of the species.

The illustrations for this paper are from drawings by Mr. Henry V. Poor, excepting fig. 1, which is from a photograph by Mr. John H. Paine, of Stanford University.

\section{Genus POLYPUS Schneider, 1784.}

POLYPUS HOYLEI, new species.

Body rounded, depressed above and below, about as long as broad, covered with a loose skin of a rather gelatinous consistency; an obscure longitudinal groove in the median ventral region. Mantle-opening small and lunate, extending but little beyond the funnel on either side.

Head broad; neck slightly constricted; eyes very large, with small openings, above which on either side are two prominent, nipple-like tubercles or cirri, each with a pore-like depression in its center. Near these are one or two fainter and smaller papillæ, and a few others, equally or more obscure, are scattered over the dorsal surface of the body.

Surface, except for the above-mentioned tubercles and papillæ, smooth, very finely reticulated with extremely minute papillæ or wrinkles, and very soft to the touch, which are apparently not due to the action of the preserving fluid.

Siphon of moderate size, bluntly conical, connected above with the basal portion of the umbrella and extending forward for about one-third the length of the latter. 
Arms rather short and stout, nearly equal, the third pair the shortest (a character especially noticeable in the male); length about twice that of the head and body taken together; umbrella very wide, extending between all the arms in the adult (male) for nearly half their length; suckers rather large and closely set, in two rows save at the base, where there is but a single row; none of those of the male showing any appreciable enlargement.

Hectocotylization affecting only a small portion of the extremity of the arm of the male, its transverse ridges rendered obscure or obsolete by the gelatinous consistency of the skin.

Color of preserved specimens a brownish-red above, more pinkish below. Chromatophores minute and numerous, especially on the upper surface, where they are quite evenly distributed in veins, the

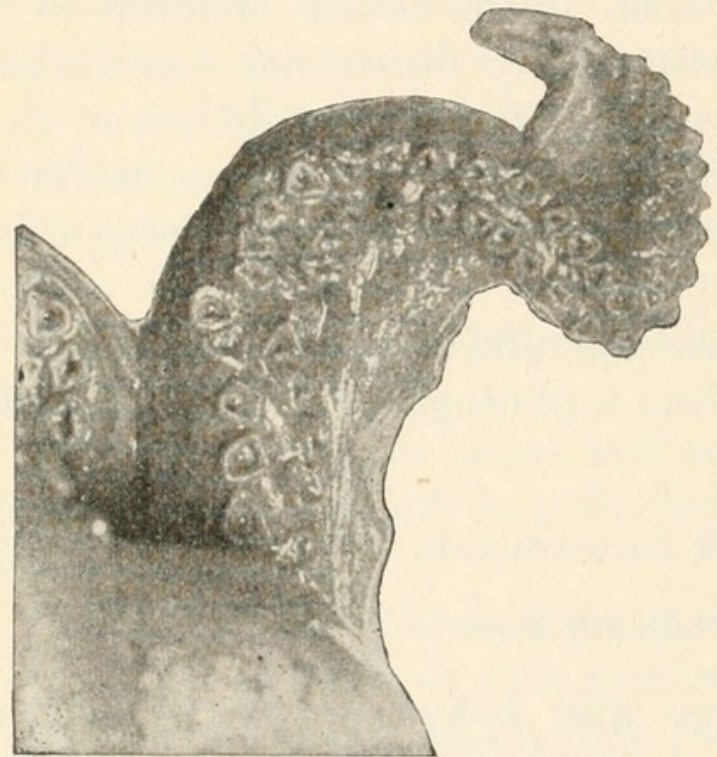

Fig. 1.-POLYPUS HOYLEI. THIRD ARM OF RIGHT Side. (Slightly Magnified.) interstices between which appear as pale reticulations upon a darker background.

Length of body $65 \mathrm{~mm}$.; of second arm-pair $161 \mathrm{~mm}$.; width of body $45 \mathrm{~mm}$. The type is a specimen obtained by the Albatross expedition, but preserved without any locality label. It is an adult male.

Further specimens are in the collection as follows: station 4110 , depth 449 fathoms, 1 young; station 4130, depth 783 fathoms, 1 male; station 4132, depth 257 fathoms, 1 female.

The present species is apparently close to $P$. januarii Steenstrup, $^{a}$ from which it is readily distinguishable by the smaller mantleopening, double cirri above the eyes, order of length of arms, their relative shortness, etc.

Named in honor of Dr. William E. Hoyle, to whom we owe much of our knowledge of this fascinating group of animals, and whose masterly memoirs are among our most important classics in their study.

STEPHANOTEUTHIS, new genus.

Body sepioliform, short, saccular. Medio-dorsal margin of mantle free from head, but articulating therewith by a very rudimentary groove and cartilaginous ridge; ventral margin produced forward below the eyes, completely covering the funnel, with the base of which it articulates on either side by a prominent cartilaginous connective apparatus. 
Fins very large, semicircular, placed somewhat posteriorly.

Head large and broad. Arms short and stout. Tentacles stout; club not expanded, but armed with a great number of very minute suckers.

Gladius none.

Type of the genus.-The following species:

STEPHANOTEUTHIS HAWAIIENSIS, new species.

Body of moderate size, sepioliform, very firm and solid, divided posteriorly by a short horizontal groove, so that the dorsal portion projects backward over the ventral as though the two halves were slid upon one another.

Mantle thick and fleshy, its anterior margin free all round and only connected with the head in the nuchal region by the merest rudiment of a cartilaginous articulation, comprising a narrow, inconspicuous, longitudinal ridge on the inner surface of the mantle and a corresponding groove or depression on the neck, without thickenings or raised edges; inner ventral surface articulated with the base of the funnel on either side by a long, prominent ridge and a corresponding heavy locking apparatus, consisting of a deep curved groove with thickened edges; anterior ventral margin of mantle produced forward beneath and past the eyes so as to conceal the funnel and the entire ventral surface of the head.

Fins very large in proportion to body; circular; attached somewhat posteriorly and considerably above the median horizontal plane.

Head large, slightly broader than the body, with large prominent eyes. Siphon rather large, obtusely conical; tip rounded, without any downward flexure.

Arms very short, the dorsal pair the longest,

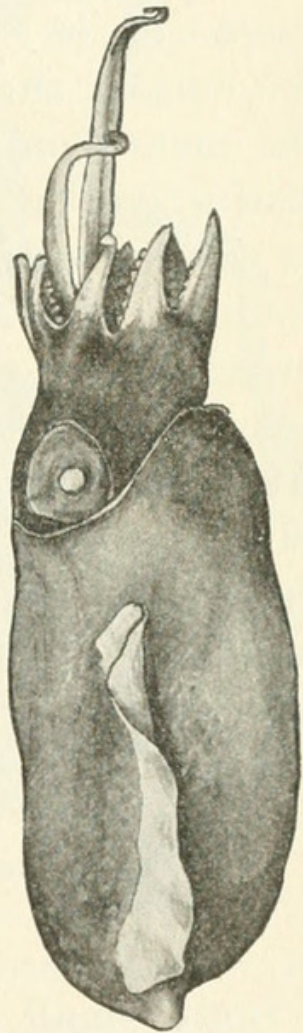

Fig. 2.-STEPHANotedthis HAWAIIENSIS. LATERAL ASPECT. $\left(\times 1 \frac{1}{2}\right)$ the third pair shortest, connected at the base by a short fleshy umbrella, which is lacking between the ventral pair; tips of the four dorsal arms recurved. Suckers small, pedunculated, in two rows, extending nearly to the tips of all the arms save the second pair where they become obsolete for much of the distal portion.

Tentacles stout, slightly tapering, with a flattened inner surface; tentacular club small, of less diameter than the stalk, and of a velvety appearance, owing to the great multitude of very minute suckers with which it is armed. 
Surface everywhere smooth. Color of preserved specimens a dirty buff, heavily dotted and reticulated with blackish chromatophores, which are most numerous on the dorsal surface of the head, but are also scattered thickly over the mantle (both above and below), on the ventral surface of the head and siphon, and at the base of all the arms except the third pair.

Gladius apparently wanting.

Total length, excluding tentacles $38 \mathrm{~mm}$; dorsal length of mantle $22 \mathrm{~mm}$.; ventral length of mantle $27 \mathrm{~mm}$.; width of mantle near middle $14 \mathrm{~mm}$; width across fins $32.5 \mathrm{~mm}$.

The unique type, a gravid female, was dredged in about 733 fathoms, station 3989, coral sand and rock bottom, in the vicinity of the island of Kauai.

This form can not, I think, be confounded with any other described species of the Sepiolidæ. In the absence of other peculiar characters, the curious shape of the body and the ventral anterior extension of the mantle entirely covering the funnel would by themselves be very distinctive, but, none the less the present form is very closely related to Heteroteuthis Gray (H. dispar (Rüppell) Gray and H. weberi Joubin). The absence of the gladius and the lack of any save the most rudimentary connection between the mantle and the head would seem to ally Stephanoteuthis with Idiosepius Steenstrup, and there are other points of resemblance as well. Idiosepius, however, is stated to have no dorsal connective cartilages whatever, is of a very different shape and aspect, and with small, more posterior, fins. According to its external characters, therefore, Stephanoteuthis seems most easily referred to the Sepiolidæ, but until an anatomical examination is possible, its exact position must be left unsettled.

\section{Genus StOLOTEUTHIS Verrill, 1881.}

STOLOTEUTHIS IRIS, new species.

Body small, short, stout, laterally much compressed, rounded posteriorly; dorsal width and length about equal and much less than the depth. Mantle smooth, broadly continuous above with the head, from which it is separated only by a rather prominent cutaneous line or fold; anterior ventral margin produced forward beneath the eyes and far past them to form a broad convex lobe, somewhat as is seen in Verrill's Nectoteuthis pourtalesii, which almost entirely conceals the funnel and the ventral surface of the head. An indentation in the free anterior edge of the lobe permits the tip of the funnel to be seen. The central region of the lobe is sharply differentiated from the rest of the mantle surface as a large, slightly raised and flattened, heart-shaped area.

Fins relatively enormous, subcircular, narrowed at the base; attached considerably above the median horizontal plane of the 
body, thin, slightly broader and longer than the body; anterior margin rounded and reaching to the eyes; posterior margin obtusely pointed, extending beyond the body.

Head very large, short and wide. Eyes large, situated in the angle of the mantle-margin above the anterior ventral lobe.

Sessile arms short, connected by a well-developed basal web reaching beyond the middle of the dorsal arms, but entirely absent between the ventral pair; order of length $3,4,2,1$, the third pair much the stoutest and longest and with the largest suckers; suckers small, pedunculated, in two rows.

Tentacles longer than the body, slightly thickened at the base, very slender and tapering; tentacular club but little, if any, wider than the stalk, armed with numerous rows of very minute suckers.

Gladius not observed; probably absent as in $S$. leucoptera.

Color in alcohol a dirty white; fins unmarked ; mantle closely speckled above and below with small brownish chromatophores of two main sizes, which decrease in number laterally and posteriorly; chromatophores evenly and thickly distributed over the ventral heart-shaped area and its immediate vicinity; ventral surface further marked by a dark bluish-

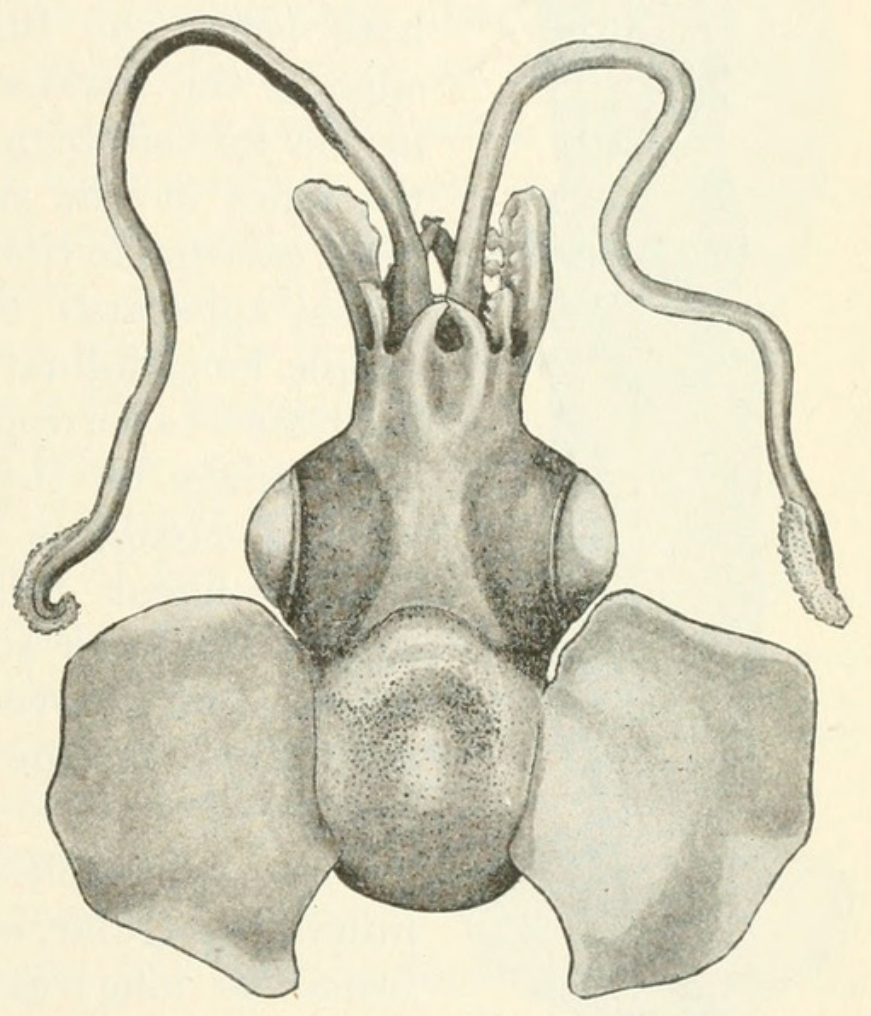

Fig. 3.-Stoloteuthis iris. Dorsal Aspect. $(\times 3)$ gray band bordering the heart-shaped area. Eyes dark gray, pupils white; arms uniformly of a dirty white.

Upon the reverse of the label accompanying the specimen appear the following notes in the handwriting of Dr. W. K. Fisher, as to the color of the animal when taken (colors according to Ridgway's "Nomenclature of Color"):

Tentacles, chromatophores burnt sienna, yellow ochre, and light red. Eye: pupil transparent, iridescent purple, blue, and emerald green; iris reddish burnt sienna. Body (except wings and outer test) iridescent orange, yellow, solferino, green, crimson, purple. Chromatophores of outer test burnt sienna and sepia.

The unique type was taken in 153 fathoms, from a bottom of brown mud and sand, at station 3832, off the south coast of the island of Molokai. Its measurements are: Length of body, excluding tentacles $16 \mathrm{~mm}$.; length of tentacles $21 \mathrm{~mm}$.; width across fins $18 \mathrm{~mm}$. 
This is an extremely distinct species, although bearing evident relationship to the S. leucoptera of Verrill and the Nectoteuthis pourtalesii of the same author, both of which are Atlantic forms. The superficial resemblance which the latter species bears to the Hawaiian form is very great, but the broad dorsal commissure uniting the head and mantle at once distinguishes $S$. iris.

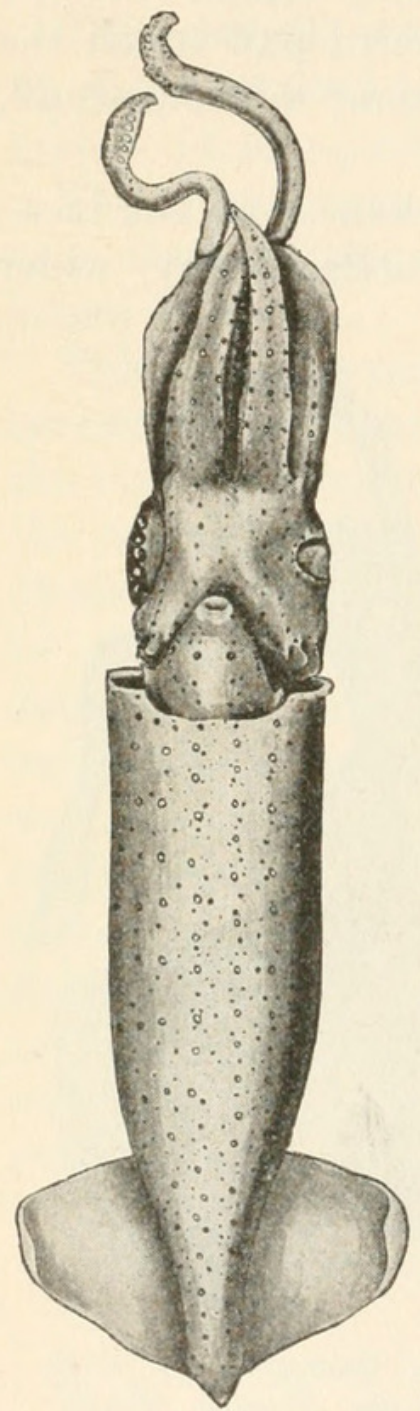

Fig. 4.-Abralia astroSticta. Ventral aspect. $\left(\times 1 \frac{1}{2}\right.$.)

eye on either side. Eyes large; orbit with a small rounded sinus in front. Funnel large, subtriangular, its center rounded and protruding ventrally, so that it has a ventrally swollen appearance.

Sessile arms rather short, the second and fourth pairs the longest; first and third pairs about equal in length; outer edge of arms furnished with a membranous or fleshy keel, which reaches its maximum development on the ventral arms. Armature consisting mainly of hooks in two alternating rows; suckers minute, appearing only at the extreme tips of the arms. 
Tentacles slender, half as long again as the arms; tentacular club armed with four rows of suckers arranged as follows: (7) two dorsal rows of small suckers, largest at the middle of the club, but extending for its entire length; (2) two ventral rows of similar suckers on the distal portion of the club, replaced proximally by (3) a single row of five or six rather large hooks; (4) at the base of the club, upon the carpus, a fixing apparatus consisting of four or five extremely minute suckers and a few pads.

Buccal membrane seven-pointed, coarsely papillose within; color uniformly pale, with a few slightly darker spots (chromatophores) scattered over the outer surface.

Photophores numerous, quite symmetrically distributed in about ten ill defined longitudinal rows on the ventral surface of the mantle; upon the ventral surface of the head five rows, one of them median; upon the funnel four rows, each comprising a single large organ and several smaller ones; upon each of the ventral arms three rows, two of them upon the body of the arm, the third extending along the marginal keel for over half its length; upon the ventral

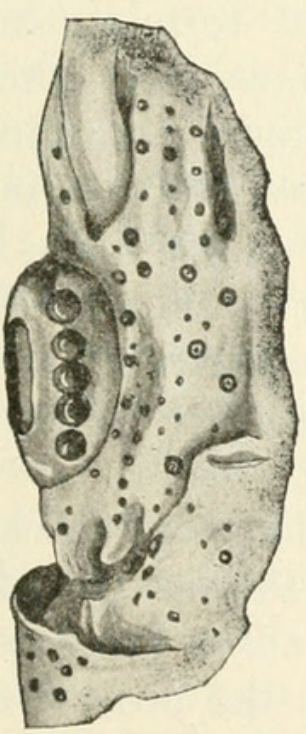

Fig. 7.-Abralia asTROSTICTA. INFERIOR SURFACE OF RIGHT EYE AND SURROUNDING REGION, SHOWING DISTRIBUTION OF LUMINOUS ORGANS. periphery of the right eyeball a very prominent row of five large, reddish, bead-like organs conspicuously different from the others. (The left eye was so retracted as to render examination impossible without mutilation

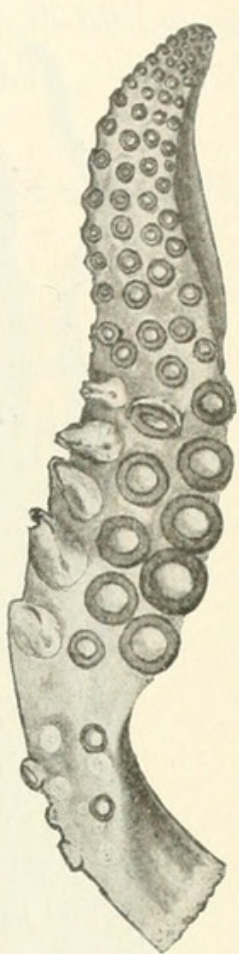

Fig. 6.-ABRALIA ASTROSTICTA. Club OF RIGHT TENTACLE. of the specimen.)

Color of preserved specimen a dirty buff, the gladius showing through the dorsal integument as a very prominent median dark line; photophores bluish, with whitish centers; chromatophores numerous, especially on the dorsal aspect, but largely replaced ventrally by the photophores.

Length, excluding tentacles $56.5 \mathrm{~mm}$.; length of mantle $34 \mathrm{~mm}$.; maximum width of mantle $10 \mathrm{~mm}$.; width across fins $22 \mathrm{~mm}$.

The type, which was the only specimen obtained, was dredged in about 192 fathoms, coarse coral sand and shell bottom-station 4122, off the southwest coast of the island of Oahu.

This species agrees with Pfeffer's "hoylei-group," of the genus Abralia, as defined by that author, ${ }^{a}$ in that "die Leuchtorgane der Ventralfläche lassen in ihrer Anordnung bilateral-symmetrische Reihenzüge erkennen" and "auf der Ventralfläche des 4. Arm- 
paares drei Reihen von Leuchtorganen, davon eine auf dem Schutzsaum, zwei auf der eigentlichen Armfläche." On the other hand, it differs from the "hoylei-group," and agrees with the "veranyigroup" (Asteroteuthis Pfeffer) in that the tentacular club possesses but one row of hooks and two rows of suckers, and also in that there is no evidence of violet coloration on the buccal membrane, although

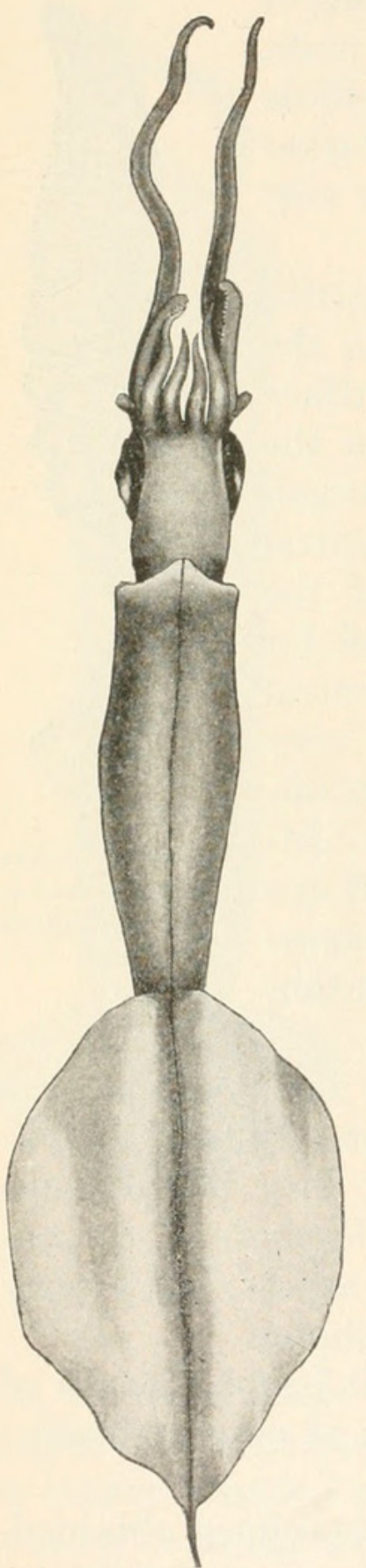

Fig. 8.-CHIRoteUthis FAMELica. DORSAl aspect $(\times 2$. the lack of this character may be due to the bleaching action of the preserving fluid. Doctor Pfeffer has suggested that the present form may represent a new genus standing midway between Abralia and Asteroteuthis, but I do not at present feel justified in adopting this view.

Genus CHIROTEUTHIS d'Orbigny, 1839.

CHIROTEUTHIS FAMELICA, new species.

Mantle cylindrical, extremely long and slender, gradually tapering for a little more than half its length, then becoming suddenly constricted to continue as an extremely slender and delicate rod between the fins, somewhat exceeding them posteriorly, and forming in this region only a thin membrane over the even more slender gladius; anterior margin sinuous, inflated; mantle connectives three in number-a longitudinal cartilage in the nuchal region, and an ear-shaped pit on either side of the base of the funnel, with corresponding cartilaginous ridges on the inner surface of the mantle.

Fins enormous, leaf-like, relatively thick and fleshy, extending for about three-fifths of the length of the mantle; about three times as long as wide; separated only by the posterior spit-like continuation of the mantle except in front, where the attached margin extends well forward on the dorso-lateral surface of the main body.

Head small, slightly narrower than the body. Eyes prominent. Funnel small.

Arms extremely short, except the ventral pair, which are enormously developed, being about three times as long as the rest, and half as long as the body; order of length, 4, $2,3,1$; umbrella and lateral membrane wanting. Suckers extremely minute, in two rows, rather widely spaced, especially those of the ventral arms; horny rings well-developed, minutely toothed. 
Both tentacles unfortunately missing.

Color of the preserved specimen a grayish buff, with a few scattered pale-brown chromatophores; gladius showing as a dark line through the integument.

Length, excluding arms $44 \mathrm{~mm}$.; length of mantle $39 \mathrm{~mm}$.; width across fins $14.5 \mathrm{~mm}$; l length of ventral arms $20 \mathrm{~mm}$.

The single known specimen was taken at station 3989, 733 fathoms depth, from a bottom of coral sand and rock, in the vicinity of the island of Kauai.

C. famelica appears to differ widely from all other known species of the genus in the extreme length and slenderness of the body and the very lanceolate fins, the smallness of the head, and the possession of relatively shorter arms than usual.

\section{Genus CRANCHIA Leach, 1817.}

CRANCHIA (LIOCRANCHIA) GLOBULA, new species.

Body subglobular, short and rounded, the diameter almost equal to the length, truncate anteriorly, posteriorly suddenly constricted, thence tapering rapidly to an acute point which forms the basis of attachment of the fins. Mantle smooth, membranous; its anterior margin passing in three even, nearly equal, curves from each point of attachment to the next. These points of attachment are three in number and about equidistant, one being dorsal and median, the other two on either side of the funnel. From the dorsal point of attachment there extends posteriorly on the outer surface of the mantle

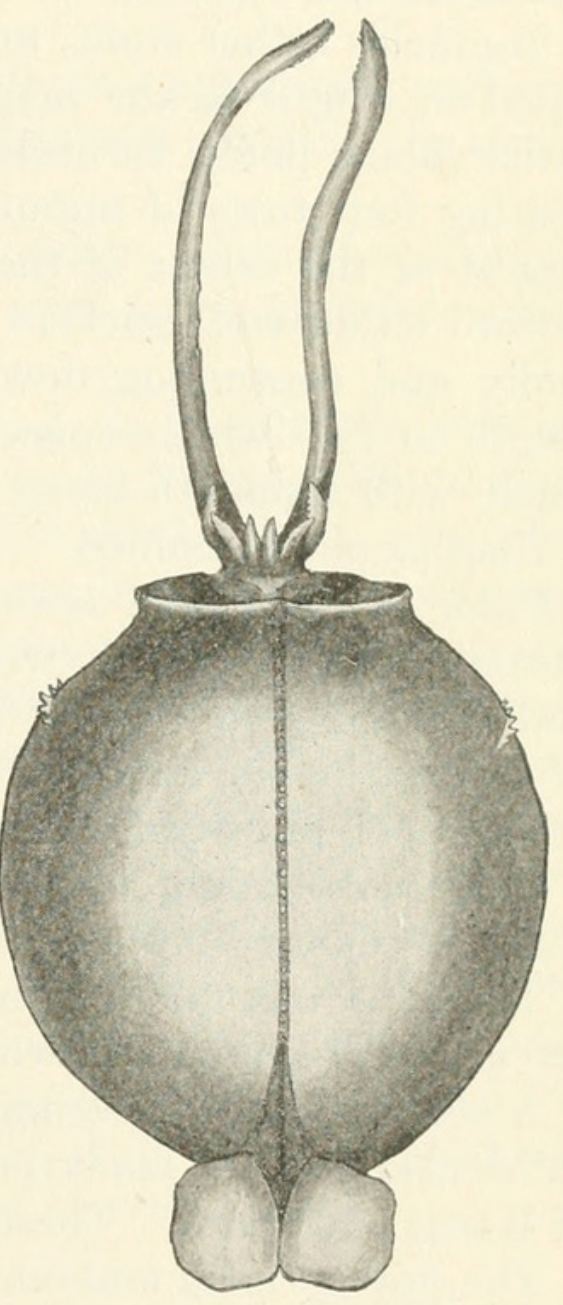

Fig. 9.-Liocranchia globula. Dorsal ASPECT. $(\times 2$. a narrow cartilaginous ridge composed of a succession of acutely conical tubercles placed close together in a single longitudinal series along the anterior two-thirds of the medio-dorsal line. From each of the ventral points of attachment two similar ridges extend back for about one-third of the length of the mantle, diverging at an angle of somewhat less than 90 degrees; the tubercles minute, of two sizes, irregularly alternating, each line comprising about twenty, arranged in a single series and flanked near the anterior end by parallel rows of two or three smaller tubercles on either side. 
Head very short and broad, projecting but slightly beyond the mantle. Eyes prominent, with a protruding lens. Funnel short, broad, projecting considerably beyond the mantle, ventrally flexed near the tip.

Sessile arms short, very unequal; order of length, $3,4,2,1$; the third pair much the longest, the second and fourth nearly equal; suckers extremely minute, pedunculated, arranged in two series of six (dorsal arms) to thirteen (third pair) each; horny rings apparently smooth; arms webbed, the umbrella extending for about one-half the length of the dorsal arms, but absent between the ventral arms and between these and the third pair.

Tentacles rather stout, much thicker than the sessile arms, almost equal in length to the mantle; club little thickened, tapering to a rather blunt point, furnished with a narrow lateral membrane, and bearing four rows of minute, closely crowded, pedunculate suckers, largest at the center of the club and becoming exceedingly minute toward either end; suckers of two of the rows much reduced proximally and continuing down the stalk for about two-thirds of its length in two widely-spaced alternating rows; aperture of suckers small, with a smooth horny ring.

Gladius not examined.

Color of preserved specimens a semitranslucent grayish white. Chromatophores distributed over the anterior portion of the mantle and extending in two rows along each tentacle, largest and most prominent on the anterior ventral surface of the mantle, where they are grouped in irregular rows to form a rough semicircle.

Length, excluding tentacles $26 \mathrm{~mm}$; length of mantle $22 \mathrm{~mm}$.; width of mantle $19 \mathrm{~mm}$.; length of tentacles $19 \mathrm{~mm}$.

The type was taken from the plankton at station 3878, south of the island of Lanai, and west of the island of Kahoolawe.

A second smaller specimen was obtained at the same station, and a third, also from the plankton, is from station 4009, between the islands of Kauai and Oahu. These agree in all essentials with the type.

The present form undoubtedly exhibits close relationship to C. reinhardtii Steenstrup, but a number of characters above noted, chief of which, perhaps, is the extreme rotundity of the body, serve to distinguish them. Lönnberg ${ }^{a}$ has considered rotundity to be merely an immature condition of $C$. reinhardtii, the latter being quite loliginiform when adult. However, the largest Albatross specimen is no less spherical than the smallest, and all are vastly more globular than any figures of $C$. reinhardtii, immature or otherwise, which I have seen. Nevertheless it is possible that a larger amount of material and a more extended knowledge of the limits of variation of these rare forms may indicate that the two are but extremes of one species.

${ }^{a}$ Lönnberg, Notes on some rare Cephalopods, p. 611, Stockholm, 1896. 
HELICOCRANCHIA Massy, 1907

HELICOCRANCHIA FISHERI, new species.

Body rather barrel-shaped, inflated. Mantle membranous, saccular, thin, colorless; attached firmly at either side of the funnel, and by a cartilaginous semiarticulation in the nuchal region, very much inflated, largest at a point nearly midway between the head and fins, somewhat tapering anteriorly and also posteriorly, where it becomes suddenly constricted and continues to a sharp point, extending as a short, slender, spit-like process between the fins; integument much wrinkled and ventrally contracted, doubtless largely due to the action of the preservative used.

Fins small, thin, circular, almost continuous posteriorly and separated in the median line only by the integument covering the slender gladius.

Head rather large, concave above and below. Funnel moderately large and with a ventral flexion. Eyes very large, globular, sessile; openings of eyelids small.

Arms short, fleshy; order of length, 4, 3, 2, 1; umbrella wanting; lateral membrane or keel well developed, heavy, fleshy, without transverse supports or commissures save on the third pair of arms; third pair of arms differing much from the others, being larger, with larger suckers and a better developed marginal membrane, strengthened by fleshy transverse supports; horny rings well developed, without teeth.

Tentacles larger and heavier than the arms, about half as long as the body; tentacular club large, expanded, tapering to an acute point, with four closely placed rows of minute suckers which extend down on to the stalk, two of them soon becoming obsolete, the remaining two continuing down the arm for about two-thirds of its length, the suckers becoming much reduced in size; suckers of the club extending distally to the extreme tip, largest near the center; club furnished with a well-developed lateral keel, inner margin of tip being supplied with a second wider membrane, parallel to and above the keel.

Gladius not examined.

Color of preserved specimen whitish, semitranslucent. Chromatophores exceedingly minute and few in number.

Ventral length of mantle $46.5 \mathrm{~mm} . ;^{a}$ width of mantle $23 \mathrm{~mm}$; width across fins $12.5 \mathrm{~mm}$. l length of tentacles $25 \mathrm{~mm}$.

The unique type was dredged in 280 fathoms, ooze bottom, at station 3883, in the Pailolo channel.

Named for Dr. Walter K. Fisher, of Stanford University, to whom the author is much indebted for many helpful suggestions and other kindnesses, and in whose laboratory this work has been carried on.

$a$ The dimensions here given are of necessity inaccurate, owing to the extremely wrinkled and contracted condition of the mantle.

Proc.N.M.vol.37-09-27 
It may be well to append herewith a list of all the species of cephalopods at present known to inhabit the waters in the vicinity of the Hawaiian Islands, including as well those obtained by the Albatross expedition. Nearly all the latter are entirely new records and it is quite possible that one or two forms, which are merely referred to their genus below, may eventually prove to be new to science, although for the time being it was deemed best to withhold descriptions of them.

\section{LIST OF THE KNOWN SPECIES OF HAWAIIAN CEPHALOPODS.}

Cirroteuthis (?), species.

Stations 3898, 3904 (very fragmentary).

Argonauta böttgeri Maltzan.

Station 3927.

Argonauta (argo Linnæus?).

Station 3857 (fragment).

Tremoctopus, species (near quoyanus d'Orbigny).

Stations 3799, 3878, 3926 3929. 3930, 3931, 4010, 4011, 4086.

Alloposus mollis Verrill.

Station 4095.

Bolitæna, species (young).

Station 4039.

Polypus hawaiiensis Eydoux and Souleyet.

Hawaii (Eydoux and Souleyet).

Polypus hoylei Berry.

Stations 4110, 4130, 4132.

Polypus marmoratus Hoyle.

Honolulu Reef (Albatross expedition).

Polypus ornatus Gould.

Station 4002 (young); Honolulu Reef (Albatross expedition); Maui (Gould).

Polypus $\alpha$ (young).

Stations 3843, 3921.

Polypus $\beta$ (young).

Stations 3821, 3837, 3905, 3907, 3911, 3912, 3921, 3926, 3930, 3980, 4011.

Polypus r (young).

Stations 3849, 3905.

Scæurgus, species.

Stations 3856, 3858, 4103.

Stephanoteuthishawaiiensis Berry.

Station 3989.

Euprymna morsei Verrill.

Stations 3821, 3829, 3846, 3856, 3857, 3859, 3889, 3896, 3905, 3926, 3931, 3980, 4010. 4071, 4073, 4102, 4103, 4152, 4153; Honolulu Reef (Albatross expedition).

Semirossia (?), species.

Stations 3900, 4088 (very fragmentary).

Stoloteuthis iris Berry.

Station 3832.

Sepioteuthis arctipinnis Gould.

Maui (Gould).

Ommastrephes sagittata near sloanei Gray.

Stations 3865, 3930, 4082, 4117, 4132, 4353 (hydrographic station); Honolulu (Albatross expedition). 
Ommastrephid (young).

Stations 3889, 3912, 3926, 3980, 4010, 4152, 4190.

Onycholeuthis banski Leach.

Laysan Island (Schauinsland).

Symplectoteuthis oualaniensis Lesson.

Laysan Island (Schauinsland).

Teleoteuthis appellöfi Pfeffer.

Station 3989.

Abralia astrosticta Berry.

Station 4122.

Abralia, species.

- Station 3926 (fragmentary).

Abraliopsis, species.

Station 3926.

Pterygioteuthis giardi Fischer.

Station 4105.

Tracheloteuthis riisei Steenstrup.

Stations 3878, 4190.

Chiroteuthis famelica Berry.

Station 3989.

Cranchia (Liocranchia) globula Berry.

Stations 3878, 4009.

Cranchiid, species.

Station 4001 (fragmentary).

Xenoteuthis fisheri Berry.

Station 3883. 


\section{$2 \mathrm{BHL}$ Biodiversity Heritage Library}

Berry, S. S. 1909. "Diagnoses of new cephalopods from the Hawaiian Islands." Proceedings of the United States National Museum 37(1713), 407-419.

https://doi.org/10.5479/si.00963801.37-1713.407.

View This Item Online: https://www.biodiversitylibrary.org/item/53183

DOI: https://doi.org/10.5479/si.00963801.37-1713.407

Permalink: https://www.biodiversitylibrary.org/partpdf/51139

\section{Holding Institution}

Smithsonian Libraries

\section{Sponsored by}

Smithsonian

\section{Copyright \& Reuse}

Copyright Status: NOT_IN_COPYRIGHT

This document was created from content at the Biodiversity Heritage Library, the world's largest open access digital library for biodiversity literature and archives. Visit BHL at https://www.biodiversitylibrary.org. 